\title{
INFLUENCE OF ECAP ON DENSIFICATION BEHAVIOUR IN THE PM ALUMINIUM Al-Mg-Si-Cu-Fe ALLOY
}

\author{
Jana Bidulská * - Tibor Kvačkaj * - Róbert Kočiško * \\ Róbert Bidulský ${ }^{* *}$ — Marco Actis Grande ${ }^{* *}$
}

\begin{abstract}
The main aim of this paper is to show how ECAP influences the densification behaviour of PM aluminium alloys. An aluminium based powder (Al-Mg-Si-Cu-Fe) was used as material to be investigated. After applying different compacting pressures, specimens were dewaxed in a ventilated furnace at $400{ }^{\circ} \mathrm{C}$ for $60 \mathrm{~min}$. Sintering was carried out in a vacuum furnace at $610^{\circ} \mathrm{C}$ for $30 \mathrm{~min}$. The specimens were ECAPed for 1 pass. Optical characterization was carried out on the minimum of 10 different image fields. The results were measured for each pore individually in order to describe the dimensional and morphological porosity characteristics. ECAP influences the porosity distribution in terms of the severe shear deformation involved.

K e y w ords: Aluminium alloy, compressibility, vacuum sintering, ECAP, densification behaviour, porosity
\end{abstract}

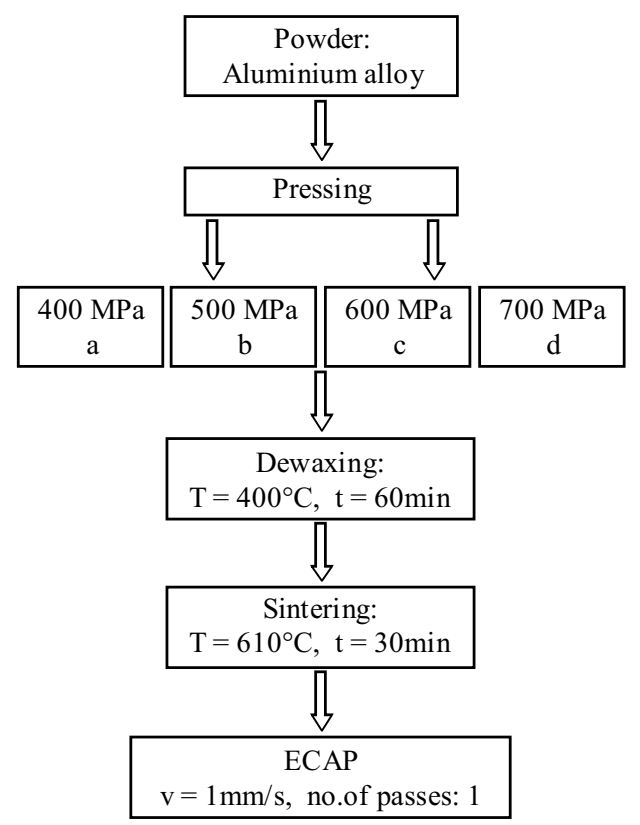

Fig. 1. Processing conditions

\section{INTRODUCTION}

Light weight aluminium alloys coupled to excellent workability, high thermal and electrical conductivity represent a good choice for the powder metallurgy (PM) industry to produce new materials having unique capabilities not available in present powder metal parts. Also the requirement on mechanical properties of high tensile strength with adequate plasticity should assure an increasing role for aluminium alloys in the expanding PM market [1].

It is well known $[2,3]$ that conventional forming methods and heat treatment can determine a limit in the level of strength-plastic characteristics adequate to structural properties. One possible way for achieving higher mechanical properties is represented by severe plastic deformation (SPD), such as Equal Channel Angular Pressing (ECAP) [4-7]. In the PM area, is a relatively new technological solution for achieving high strength [8,9].

The main aim of this paper is to show how ECAP influences the densification behaviour of PM aluminium alloys.

\section{EXPERIMENTAL CONDITIONS}

A commercial ready-to-press aluminium based powder (Al $-0.95 \mathrm{Mg}-0.49 \mathrm{Si}-0.21 \mathrm{Cu}-0.07 \mathrm{Fe}-1.6$ lubricant) was used as material to be investigated.

Particles size distribution was carried out by sieve analyzer according to ISO 4497. After applying different compacting pressures (400, 500, 600 and $700 \mathrm{MPa})$, specimens were dewaxed before sintering in a ventilated furnace type (Nabertherm) at $400{ }^{\circ} \mathrm{C}$ for $60 \mathrm{~min}$. Sintering was carried out in a vacuum furnace (TAV) at $610^{\circ} \mathrm{C}$ for $30 \mathrm{~min}$, with an applied cooling rate of $6{ }^{\circ} \mathrm{Cs}^{-1}$. The ECAP was realized by hydraulic equipment at room temperature, which makes it possible to produce the maximum force of $1 \mathrm{MN}$. The specimens were ECAPed for 1 pass. Processing conditions are shown in Fig. 1.

Optical characterization was carried out on the minimum of 10 different image fields. For the determination of

\footnotetext{
* Department of Metals Forming, Technical University of Košice, Letná 9, 04200 Košice, jana.bidulska@tuke.sk; ** Politecnico di Torino, Alesssandria Campus, Viale Teresa Michel 5, 15100, Alessandria, Italy
} 
Table 1. Densification behaviour of investigated material as values of theoretical density \%, except $\Psi$

\begin{tabular}{cccccc}
\hline No. & Pressing & Dewaxing & Sintering & $\Psi$ & ECAP \\
\hline a & 92.48 & 93.11 & 92.12 & -0.05 & 98.31 \\
b & 92.84 & 93.30 & 92.40 & -0.06 & 98.39 \\
c & 93.03 & 92.89 & 92.82 & -0.03 & 98.64 \\
d & 93.19 & 92.93 & 93.09 & -0.01 & 98.58 \\
\hline
\end{tabular}

Table 2. Porosity distribution of studied material before ECAP

\begin{tabular}{cccc}
\hline No & $D_{\text {circle }}$ & $f_{\text {shape }}$ & $f_{\text {circle }}$ \\
\hline a & 30.64 & 0.70 & 0.92 \\
b & 30.20 & 0.72 & 0.93 \\
c & 23.64 & 0.69 & 0.92 \\
d & 21.27 & 0.64 & 0.89 \\
\hline
\end{tabular}

Table 3. Porosity distribution of studied material after ECAP

\begin{tabular}{cccc}
\hline No & $D_{\text {circle }}$ & $f_{\text {shape }}$ & $f_{\text {circle }}$ \\
\hline a & 0.97 & 0.67 & 0.91 \\
b & 0.90 & 0.65 & 0.91 \\
c & 0.85 & 0.67 & 0.91 \\
d & 0.79 & 0.64 & 0.90 \\
\hline
\end{tabular}

porosity characteristics $100 \times$ magnification were used for specimens prepared by pressing and sintering and $500 \times$ for ECAPed specimens. Pores were recorded and processed by Leica Qwin image analysis system. $D_{\text {circle, as }}$ the diameter of the equivalent circle, and the morphological characteristics $f_{\text {shape }}$ and $f_{\text {circle }}$ were measured for each pore individually in order to describe the dimensional and morphological characteristics. The calculations of both parameters are reported as follows

$$
f_{\text {shape }}=\frac{D_{\min }}{D_{\max }}=\frac{a}{b},
$$

where $D_{\min } \mu \mathrm{m}$ is the parameter representing minimum of Feret diameter; $D_{\max } \mu \mathrm{m}$ is the parameter representing maximum of Feret diameter, and

$$
f_{\text {circle }}=\frac{4 \pi A}{P^{2}}
$$

where $A \mu \mathrm{m}^{2}$ is the area of the metallographic crosssection of the pore; $P \mu \mathrm{m}$ is the perimeter of the metallographic cross-section of the pore. The calculations of both parameters $A$ and $P$ are reported as follows

$$
\begin{aligned}
& A=\pi a b, \\
& P=\pi[1.5(a b)-\sqrt{a b}] .
\end{aligned}
$$

Densification $\Psi$ was calculated to determine the amount of shrinkage or swelling during sintering:

$$
\Psi=\frac{\rho_{s}-\rho_{g}}{\rho_{t}-\rho_{g}},
$$

where $\rho_{s}\left(\mathrm{~g} \mathrm{~cm}^{-3}\right)$ is the sintered density, $\rho_{g}$ is the green density $\left(\mathrm{g} \mathrm{cm}^{-3}\right)$ and $\rho_{t}$ is theoretical density $\left(\mathrm{g} \mathrm{cm}^{-3}\right)$.

\section{RESULTS AND DISCUSSION}

\subsection{Powder Characterization and Densification Behaviour}

Particle size distribution of the powder is in the range of $63-100 \mu \mathrm{m}$ ( $48.8 \%$ fraction) and in the range $100-160 \mu \mathrm{m}$ ( $28.7 \%$ fraction). It can be seen that dominate particle size is $\sim 100 \mu \mathrm{m}$. Squared specimens of size $55 \times 10 \times 10 \mathrm{~mm}^{3}$ were pressed at pressures in the range of 400-700 MPa to study the compaction characteristics. The results presented in Tab. 1 .

The maximum green density of $\sim 2.53 \mathrm{~g} \cdot \mathrm{cm}^{-3}$ of compacts is obtained at $700 \mathrm{MPa}$ with a level of $93 \%$ of theoretical density.

It can be seen that with increasing pressing pressure, in the values of theoretical density increase. It is well-known that aluminium powder would not require much sintering because its relative softness allows very high green densities to be obtained by compaction alone, as well green densities in excess of $90 \%$ are typical. Indeed, sintering of aluminium often causes swelling and results in negative densification values [10-13]. A high heating rate in transient systems also promotes liquid formation because it limits the time available for dissolution of the additive in the base prior to melting. ECAP process can be sufficient to achieve a good densification. Also, the presence of adsorbed and absorbed gases by the Al particles, as well as water vapour present during vacuum sintering [14] would increase the size of the compacts and therefore reducing their sintered density due to volume expansion.

\subsection{Porosity Distribution}

Table 2 shows the values of porosity characteristics for the investigated material processed before ECAP.

As expected, the sintering tends to the formation of secondary porosity during transient LPS as well as the swelling presented seems to be related to the amount of liquid generated. The formation of secondary pores, according to [11-13] is dependent on the previous formation of a liquid able to migrate away from the site of the prior alloying particles. The mix of primary (which still present in studied materials), secondary and residual porosity reveals the mean values of $D_{\text {circle }}$ decreased with increasing pressing pressure. As expected, the coarse additive particle sizes leave large residual pores behind. Sintering under vacuum gave rise to the presence of higher pore content and excessive amounts of residual porosity at grain boundaries.

Application of ECAP supported next decreasing of pore size, represented by the value of $D_{\text {circle }}$, Tab. 3 . 
It can be noted that most of the pores diameter values are less than $1 \mu \mathrm{m}$. It could be expected that this large amount of small pores-nanoporosities, strongly influences both $f_{\text {shape }}$ and $f_{\text {circle }}$ considering that small pores evolve easily to a circular form despite of wellknown ability of ECAP to alignment of particles and porosity $[8,15]$.

\section{CONCLUSION}

Coupling the experimental results obtained and the literature analysis it is possible to the achieved following conclusions:

1. ECAP influences the porosity distribution in terms of the severe shear deformation involved.

2. The application of SPD induced the stress distribution in deformed specimens causes the powder particles to squeeze together to such an extent that the initially interconnected pores transform to small isolated pores, determining a given value of the parameter $D_{\text {circle }}$ and therefore influences the pore morphology which is represented by both $f_{\text {shape }}$ and $f_{\text {circle }}$.

\section{Acknowledgements}

J. Bidulsk thanks the Bilateral Project SK-PL-001109. R. Bidulsk thanks the Politecnico di Torino and the Regione Piemonte for co-funding by the fellowship.

\section{REFERENCES}

[1] BIDULSKÁ, J.-KVAČKAJ, T.-KOČIŠKO, R.-BIDULSKÝ, R.-GRANDE, A. M.-DONIČ, T.-MARTIKÁN, M. : Acta Phys. Pol. A 117 No. 5(2010), 864-868.

[2] KVAČKAJ, T.-BIDULSKÁ, J.-FUJDA, M.-KOČIŠKO, R.-MILKOVIČ, O.: Mater. Sci. Forum 633-634 (2010), 273-302.

[3] BIDULSKÁ, J.-KVAČKAJ, T.-BIDULSKÝ, R.-GRANDE, A. M.: Kovové Mater. 46 No. 6 (2008), 339-344.

[4] VAliEV, R. Z.-LANGDON, T. G. : Progr. Mater. Sci. 51 No. 7 (2006), 881-981.

[5] BIDULSKÁ, J.-KVAČKAJ, T.-BIDULSKÝ, R.-GRANDE, A. M. : High Temp. Mater. Process. 27 No. 3 (2008), 203-207.

[6] KOČIŠKO, R.-KVAČKAJ, T.-BIDULSKÁ, J.-MOLNÁROVÁ, M.: Acta Metallurgica Slovaca 15 No. 4 (2009), 228-233.

[7] BIDULSKÁ, J.-KVAČKAJ, T.-KOČIŠKO, R.-BIDULSKÝ, R.-GRANDE, A. M.: Acta Metallurgica Slovaca 16 No. 1 (2010), 4-11.

[8] LAPOVOK, R. Y.: J. Mater. Sci. 40 No. 2 (2005), 341-346.

[9] WU, X.-XU, W.-XIA, K.: Mater. Sci. Eng. A 493 (2008), 241-245.

[10] LUMLEY, R. N.-SCHAFFER, G. B.: Scr. Mater. 39 No. 8 (1998), 1089-1094.

[11] MARTN, J. M.-NAVARCORENA, B.-ARRIBAS, I.-GÓMEZ-ACEBO, T.-CASTRO, F. : In.: Euro PM 2004 (H. Danninger, R. Ratzi, eds.), vol. 4,, Wien, 2004, pp. 46-53.

[12] DANNINGER, H. : Powder Metall. 30 No. 2 (1987), 103-109.

[13] MARtN, J. M.-CASTRO, F.: Int. J. Powder Metall. 43 No. 6 (2007), 59-69.
14] ShOWAiter, N.-YOUSEFFI, M.: Mater. Des. 29 (2008), $752-762$.

15] LAPOVOK, R. Y.-TOMUS, D.-MUDDLE, B. C.: Mater. Sci. Eng. A 490 (2008), 171-180.

Received 30 June 2010

Jana Bidulská (Dr) was born in Košice (Slovakia), in 1977. She received the Materials Engineer degree in 2000, the $\mathrm{PhD}$ degree in Metallurgical Engineer in 2008. She is Deputy Head of Department of Metals Forming, Member of board of state examiners in field of study Materials and programme of study, Metal forming. Her scientific work deals with the new progressive materials (steels and aluminium alloys) and processing (Equal Channel Angular Pressing, Equal Channel Angular Pressing — back pressure, Heat Treatment including a new progressive technique).

Tibor Kvačkaj (Prof) was born in Podbrezová (Slovakia), in 1952. He received the Metallurgy Engineer degree in 1976, the $\mathrm{PhD}$ degree in Metallurgy of Metals in 1982, today he is the full professor for Metallurgy of Metals in 2000 at Technical University of Košice, Slovakia and Head of the Department of Metals Forming. He is author or co-author of 44 publications and is chairman of international editorial board of scientific and technological journal Acta Metallurgica Slovaca and member of editorial scientific committee of journal Acta Universitatis Pontica Euxinus. He has experience in research and development for steels and steel technologies, physical and mathematical simulations of plastic deformations, phase transformations and nanoscale structure formation.

Róbert Kočiško (Dr) was born in Košice (Slovakia), in 1981. He received the Materials Engineer degree in 2005, the PhD degree in Metallurgical Engineer in 2009. His scientific work deals with the new progressive materials (steels and high purity copper and aluminium) and processing (Equal Channel Angular Pressing, Equal Channel Angular Pressing — back pressure, Heat Treatment including a new progressive technique).

Marco Actis Grande (Dr) was born in Cuneo (Italy), in 1973, in 1999 he got his MSc in materials engineering at Politecnico di Torino (Italy), with thesis at the University of Nottingham (UK) and got the PhD degree in 2005 from Politecnico di Torino. Curretly is Assistant Professor in Metallurgy; member of editorial board of Powder Metallurgy Progress journal. His scientific work is mainly focused on the metallurgical aspects related to sintered materials.

Róbert Bidulský (Dr) was born in Košice (Slovakia), on the 14th of March 1977. He received the Materials Engineer degree in 1997, the PhD degree in Metallurgical Engineer in 2000 at Technical University of Košice. He is a member of editorial board of Acta Metallurgica Slovaca journal. His scientific work focused on the materials science (powder metallurgy, Equal Channel Angular Pressing) Heat Treatment processing (sinter hardening), as well physical and mathematical simulation (compressibility, diffusion and material flow phenomena). He published more than 90 papers. He was awarded fellowships for foreign senior researcher at Politecnico di Torino.

This work was presented at Nanoved \& Nanotech \& Techtransfer 2010, International Conference on Nanoscience, Nanotechnology, Nanomaterials, Nanomedicine and Transfer 16-19 May 2010, Bratislava, Slovakia. 